\title{
Allocation of Internally Generated Corporate Cash flow in Africa
}

\begin{abstract}
We examine how managers of African firms, operating in environments characterised by less developed capital markets and weak institutional structures, make use of their internally generated cash flows. We find that managers of African firms hold most of their internally generated cash flows, and when they decide to spend, they allocate a higher proportion towards dividend payments; followed by leverage adjustments; then to investments; and lastly, to equity repurchases. These allocations are consistent with the existence of a significant financial constraint in African markets, and the use of dividends to signal credit quality in relatively underdeveloped capital markets.
\end{abstract}

Keywords: Financial constraints, cash flow, cash holdings, investments, dividend, Africa. 


\section{Introduction}

The efficient allocation of internally generated cash flows (cash flows, henceforth) is one of the vital roles of corporate managers, especially when firms are likely to face external financing constraints. Managers can choose to spend corporate cash flows on new investments, pay dividends, reduce or increase existing debt or equity stocks, or buffer cash reserves to hedge against future capital shortfalls (Chang et al., 2014). Since there are benefits and costs associated with each of the cash flow uses, allocations of cash flows have implications on the viability of firms, especially those operating in underdeveloped African capital markets. Most African economies are characterised by limited access of firms to external capital and weak institutional infrastructure (e.g. legal systems, political/corporate governance structures, etc.) (see Misati and Nyamongo, 2011; Gwatidzo and Ojah, 2014). Moreover, economic uncertainty regarding the frequent policy changes and reversals coupled with political instability in most African countries imply greater operational/business risk (Biggs and Shah, 2006), which may translate into weaker future operating profits/cash flow (Collier and Gunning, 1999) and further worsen the financing problems faced by African firms.

Against this background, we posit that managers of African firms would prefer to save current cash flows rather than spend since cash holdings have a higher premium under conditions characterised by financing constraints (see Olper et al., 1999; Faulkender and Wang, 2006; Archarya et al., 2012). In other words, the fear of not being able to access external financing easily and/or raise sufficient internal funds in the future should make the current internally generated cash flows an extremely valuable organisational resource for African firms, and lead them to hoard current cash as a hedging tool against future shortfalls in external (or even internal) financing. We find results that are consistent with this prediction. Specifically, managers of African firms save a higher proportion of their internally generated cash flows, and when they decide to spend, they tend to prioritise dividend payments over investment, debt repayments, and equity repurchases. This high allocation to cash holdings is consistent with the need to buffer current cash reserves as a hedge against future cash shortfalls, which may be difficult to cover in relatively underdeveloped capital markets.

The high allocation to dividend payments, ahead of capital expenditure suggests a high desire by firms in emerging markets to signal their quality to alleviate the high information asymmetry problems 
(Fosu, 2014). ${ }^{1}$ Also, by choosing to save and/or pay dividends, managers of African firms seem to exhibit a high level of risk aversion and a propensity to under-invest. These results are robust to controlling for the dynamic nature of corporate decisions, and factors that may affect cash flow allocations (e.g. growth opportunities, firm size, asset tangibility, debt levels, and current cash holdings).

Our study is important for at least four related reasons. First, we add to our understanding of how managers of African firms allocate cash flows among competing needs (i.e. cash holdings, dividend payments, investments in capital expenditure, and debt or equity repayments/issuance). Thus, we throw some light on corporate or managerial choices in environments of underdeveloped capital markets and weak institutional infrastructure. Second, since our analysis of cash flow uses includes investments, we contribute to the existing literature on investment-cash-flow-sensitivity (ICFS, hereafter) which has mostly focused on firms in advanced economies (notably, the US). Whether the conclusions drawn from firms in the advanced countries hold for other firms in developing economies remains an open empirical question, to which we seek to address. Specifically, to the best of our knowledge and based on our extensive search of the literature, this article is the first to provide insights on cash flow sensitivities based exclusively on firms from African economies. ${ }^{2}$ Third, we provide a more extensive analysis of how firms spend their incremental cash flows by focusing on all uses of cash rather than the piecemeal approach in the literature. In particular, our analysis shows that beyond investments in capital expenditure, the other cash flows uses (i.e. cash holdings, dividend payments, and adjustments in debt and equity capital) which have been largely overlooked in the literature are important for understanding the effects of financial constraints on corporate decisions. Finally, there is very little theoretical guidance on how the degree of financial constraints may influence the allocation of cash flows. For instance, it is unclear whether a financially constrained firm should invest more or less or pay more or less dividends. In this regard, our early empirical evidence on the cash flow allocations of African firms could be a step in the right direction in informing theory development in this area.

Our results have important implications for economic policy and corporate practice. Since the use of cash typically affects economic growth and development, our finding of high cash hoarding by firms should prove worrisome to policymakers in African countries who are keen to accelerate economic 
growth and development and to help them formulate or reform their economic policies to get firms to invest more in long-term capital projects. Another key implication of our results is that the adverse external operating environment of firms may influence managerial risk appetite by making corporate managers commit liquid resources to "low-risk low-return" courses such as cash holdings and dividend payments.

Next, we review the literature that helps to set the scene for our empirical analysis. Then, we describe the empirical methodology and the data utilised in the paper, followed by a discussion of the results as well as some robustness tests. Finally, Section 6 concludes the paper.

\section{Related literature}

\subsection{Corporate cash flows and financing constraint}

Extant research into firms' financing decisions suggests that the presence of frictions such as information asymmetry, agency problems, uncertainties, among others, makes the source and type of finance that managers choose matter for firm value (Modigliani and Miller, 1963; Myers and Majluf, 1984; Agyei-Boapeah, 2015). More broadly, firms can raise funds internally (via operating cash flow) or externally (through debt or equity issuance), and the capital market frictions (e.g. information asymmetry) lead to some additional costs (direct and indirect). This makes external capital relatively expensive especially for firms that face significant financial constraints (Myers and Majluf, 1984; Brav, 2009).

One of such costs associated with external finance is the upfront (direct) transaction costs incurred by firms when raising equity or debt capital from capital markets or financial institutions. For their sample of US firms during 1990-1994, Lee, Lochhead, Ritter, and Zhao (1996) report that the average direct costs of equity issuance ranges from $7 \%$ to $11 \%$ of the proceeds, while the direct costs of debt are relatively lower, around $2-4 \%$. They further report that the transaction costs of raising new equity and debt capital is substantially higher in their sub-sample of financially constrained firms. For example, when they utilise credit rating to partition their sample into financially constrained and unconstrained firms, they report the direct costs of raising straight bonds to be only $0.9 \%$ for unconstrained firms, compared to $3.4 \%$ for their constrained counterparts. Thus, firms that are likely to be financially 
constrained may need to actively look for competitive alternatives to external finance if they need to be able to support their operations and future investments.

Related literature elsewhere focusing on corporate liquidity (e.g. Opler et al., 1999; Almeida et al., 2004; Faulkender and Wang, 2006) suggest that internally generated cash flows, being an alternative to external finance, are important for firms, especially those that are likely to face significant financial constraints. Corporate cash flows enable firms to service contractual debt payments and therefore reduce the risk of financial distress, as well as offer firms the ability to undertake investments without having to access external capital markets, and to thereby avoid both transaction (direct) costs and information asymmetry (indirect) costs on debt and equity issues.

Empirically, Fazarri, Hubbard, and Petersen (1998) provide early evidence of a positive relationship between internally generated cash flow and investment. They further find this relationship to be more pronounced for firms that are most likely to have difficulty accessing the external capital market. The authors conclude that there is a significant difference between the costs of internal and external financing and that capital market frictions may cause financially constrained firms to forgo some positive NPV projects. Other studies including Boyle and Guthrie (2003) and Pawlina and Renneboog (2005) support the original findings of Fazarri et al. (1988), while others (e.g. Kaplan and Zingales, 1997; and Chen and Chen, 2012) find inconsistent results. It is noteworthy that all these studies have been conducted in the context of advanced economies, notably the US, and have therefore relied on imperfect proxies in gauging firms' levels of financial constraint. Thus, the analysis of African firms in the present study offers a useful addition to this literature by exploring the issue of investment-cashflow-sensitivity within the African context where external financing constraints may be more prevalent.

Similarly and with respect to cash holdings, Almeida, Campello, and Weisbach (2004) examine the cash flow sensitivity of cash, based on the idea that firms with investment opportunities but have limited or no access to external capital markets (constrained firms) will save cash out of their current cash flows when they anticipate the need for resources for future investments. In contrast, unconstrained firms will not engage in such liquidity management since they can easily obtain external finance when the need arises. Using US and G-7 countries, Almeida et al. (2004) and subsequently Khurana, Martin, and Pereira (2006) show that financially constrained firms exhibit a positive sensitivity of cash flow to cash, 
while unconstrained firms exhibit no such systematic sensitivity. More recently, Tsoukalas, Tsoukas, and Guariglia (2017) propose a framework which incorporates investment regimes (low vs. high) into Almeida et al.'s (2004) model. They argue and provide evidence to suggest that firms that face costly external finance use cash to transfer resources from periods of low (or no) investments to periods of high investments. Put differently, firms accumulate cash (save) during inaction periods and use the previously accumulated cash during investment spikes. They conclude that firms' cash policy follow a step-like function (i.e. high-low-high-low).

Empirical studies of corporate cash holdings (e.g. Olper et al., 1999; Harford, 1999; Almeida et al., 2004) find that firms with better growth opportunities, riskier cash flows, and limited access to capital markets hold higher cash balances. This suggests that constrained firms with growth prospects are more reliant on internal funds and therefore hold higher levels of cash than do firms that can easily access more funds externally when they need it. Faulkender and Wang (2006) go beyond the determinants of corporate cash holdings to consider the value that the market places on cash holdings. They argue that for firms that face greater financing constraints, the marginal value of cash should be higher than for firms that can easily raise additional capital. An additional internally generated cash flow enables a constrained firm to avoid the higher costs of raising external funds, thereby rendering additional internal funds relatively more valuable. Based on their predominantly US sample over the period 1971-2001 and employing access to public debt markets as a proxy for financial constraints, they find that the estimated marginal values of $\$ 1$ cash generated are $\$ 1.15$ and $\$ 0.73$ for financially constrained firms and unconstrained firms, respectively. These results demonstrate that the market perceives difficulty in accessing capital markets to be costly, and therefore, reward constrained firms with higher valuations for holding cash that helps them to mitigate potential underinvestment.

Collectively, the existing literature on corporate cash flows suggests that the presence of substantial transaction costs of raising external finance makes internally generated cash flows a critical resource for firms that are likely to face significant external financing constraints. If indeed, most African firms operate in environments where it is more difficult to access capital markets, then operating cash flow becomes a valuable asset of African firms and how managers deploy cash flow becomes essential for 
firm value as well as economic growth. These considerations, among others, make the cash flow allocations of African firms a matter worthy of a careful inquiry.

\subsection{The African environment}

Prior studies have persuasively established that the ability of firms to raise external finance is strongly influenced by the economic, financial, and legal environment in which it operates (Rajan and Zingales, 1998; La Porta et al., 1997). Accordingly, the enforcement of contracts, the quality of governance, and the level of financial market development affect the cost of external capital faced by firms. Legal systems with ineffective contract enforcement and higher agency (moral hazard) problems make it more challenging to obtain long-term finance (La Porta et al., 1997). Rajan and Zingales (1998) argue that well developed financial markets and institutions help firms to overcome moral hazards and adverse selection (information asymmetry) problems, thereby reducing the costs of raising external finance for firms. By contrast, these problems are exacerbated in countries with underdeveloped financial markets and weaker institutions that protect investors' interests, thereby raising the costs of external funds for firms in such economies.

Most developing countries, particularly those across the African continent, share some features that reduce shareholder rights and expose them to severe agency problems (Agyei-Boapeah, 2015; Gyapong, Monen, and $\mathrm{Hu}, 2016)$. First, inadequate corporate information disclosures and the absence of wellfunctioning public credit information sharing systems in many African economies (Fosu, 2014), exacerbate the information asymmetry problems in financial markets and make it more difficult for firms to access external finance at reasonable costs. Second, financial and insurance markets in most African economies are in their nascent stages (Gwatidzo and Ojah, 2014), rending them relatively underdeveloped, and thereby limiting access to external capital on the continent (Ntim and Tunyi, 2016). Third, the legal and judicial systems in the region are plagued by obsolete laws and bureaucratic procedures, insufficient resources, and corruption (Biggs and Shah, 2006), that results in public perception of a legal and judicial system that is unworkable, too costly, and slow for resolving commercial disputes. Finally, the economies of most African countries are prone to shocks - periodic weather-related distress in agriculture, civil conflicts, terms-of-trade shocks, frequent policy changes, 
infrastructure breakdowns, among others (see Collier and Gunning, 1999). These shocks to the economic system tend to cause unanticipated changes in prices and transaction costs, resulting in unexpected changes in firms' cash flows. In such shock-prone circumstances, firms find it difficult to raise external finance, leading to significant financial constraints for most African firms.

Although there are studies that address the effect of these economic and institutional challenges on the economic growth and development of African countries (e.g. Collier and Gunning, 1999), empirical research on the effect of these challenges faced by African economies on access to external capital remains mostly unexplored. A notable exception is a study by Gwatidzo and Ojah (2014) based on a survey of firms in 11 African countries conducted between 2002 and2006. They find that variables for economic/political stability and the quality of the legal systems across African countries are statistically and positively related to firms' access to debt financing. They conclude that economic/political instability and the poor legal environment in which most African firms operate impede their ability to access external finance.

Overall, the foregoing discussions appear to support our argument that since most African firms operate in environments of significant external financing constraints, they will immensely value their internally generated operating cash flows in order not to forgo potentially profitable projects. Therefore, we examine how African firms allocate their internally generated cash flows across the competing uses. Our study relates to the recent research by Gatchev, Pulvino, and Tarhan (2010) and Chang et al. (2014) and Lewellen and Lewellen (2016) who examine cash flow spending by firms in advanced economies (mostly the US) on investments, financing, and distributions to shareholders (e.g. dividend payments and share repurchases). For example, Gatchev et al. (2010) report that financing-cash flow sensitivities dominate investment cash flow sensitivities. When cash flow increases by $\$ 1$, leverage declines by $\$ 0.76$, while investments increase by only $\$ 0.16$. They conclude that firms respond to lower (higher) cash flows primarily by increasing (paying down) debt. The question we ask in this article is whether African firm also allocate their cash flows in this manner, given the institutional environment they find themselves.

\section{Data and methods}




\subsection{Estimation methods}

Drawing from the cash flow identity methodological argument (see Chang et al., 2014), we utilise an integrated regression framework in which all the identified cash flow uses are interrelated by the identity that the sum of all cash flow uses must equal the value of cash flow itself. This cash flow identity, in theory, implies that the sum of the cash flow sensitivities of all the uses (if the list is exhaustive) must equal unity. That is, if cash flow increases by a currency unit (say, \$1.00), the incremental allocation to all the cash flow uses must also sum to a currency unit (i.e. \$1.00).

Our baseline empirical models [specified below in Eq. (1)] regress the major uses of cash flow (i.e. cash holdings, dividends, capital expenditure, change in debt, and change in equity) on cash flow and a set of control variables. Together, these items (cash holdings, dividends, capital expenditure, change in debt, and change in equity) provide a nearly complete picture of how firms spend cash flow. ${ }^{3}$

$Y_{i t}=\left[\begin{array}{l}\Delta \text { Cash }_{i t} \\ \Delta \text { Div }_{i t} \\ \Delta \text { Capex }_{i t} \\ \Delta \text { Debt }_{i t} \\ \Delta \text { Equity }_{i t}\end{array}\right]=\alpha+\phi C F_{i t-1}+\beta X_{i t-1}+\eta_{i}+\eta_{t}+\varepsilon_{i t}$

where $Y_{i t}$ is a vector of cash flow uses (i.e. cash holding, dividends, investment in capital expenditure, and changes in debt and equity) for firm $i$ at time $t$; $\alpha$ is the constant; $\varphi$ and $\beta$ are vectors of parameters to be estimated; $C F_{i t}$ is the cash flow; $X_{i t-l}$ is a vector of lagged control variables (explained below); $\eta_{i}$ represents time-invariant unobservable firm-specific effects; $\eta_{t}$ represents time-specific effects; and $\varepsilon_{i t}$ it is an error term. Guided by work in the cash holding and capital structure literature (e.g. AgyeiBoapeah, 2015), the control variables (defined in Appendix A) include market-to-book ratio, asset tangibility, firm size, leverage, and cash balance.

It is important to highlight that the parameter estimates $(\varphi)$ for the cash flow variable $\left(\mathrm{CF}_{i t}\right)$ in Eq. (1) represent the sensitivity of a particular use of cash to internally generated cash flow. Thus, $\varphi$ is interpreted in the present article as the proportion of current cash flow allocated to a specific use, and it is the magnitude as well as the statistical significance of this parameter $(\varphi)$ that are of primary interest to us. We further control for country-, industry-, and time-specific effects by the use of dummies, but these are unreported in the results to conserve space. 
We estimate Eq. (1) using pooled ordinary least squares (OLS) regressions to enable us compare our findings with prior studies. Moreover, OLS estimation helps us to preserve our sample size since instruments are required to warrant imposing additional restrictions on our data. ${ }^{4}$ However, OLS estimation may result in biased and/or inconsistent parameter estimates due to its inability to deal with endogeneity problems relating to omitted variables and measurement errors. We, therefore, test the robustness of our findings to these econometric challenges by applying a system Generalised Method of Moments (sys-GMM) estimation technique on a relatively smaller (reduced) sample.

The sys-GMM is designed to minimize these econometric concerns (Chang et al., 2014; Amit, 2015) by accommodating the fact that most corporate decisions (e.g. investment and capital structure) are not static but follow a partial adjustment towards equilibrium (Fosu, 2014). Thus, it includes a lagged dependent variable to controls for persistence and thereby minimizes endogeneity problems resulting from omitted variables (Amit, 2015). However, the lagged dependent variables are, by construction, correlated with the differenced error term.

Arellano and Bond (1991) propose the difference GMM estimator, which uses the lagged levels of the endogenous variables as instruments, to circumvent this problem. As shown in Blundell and Bond (1998), lagged levels of the explanatory variables can perform poorly in the first-differences equation, possibly due to persistence or measurement errors. Therefore, to improve efficiency, the equation in levels may be combined with the differenced equation to form a system of equations (Blundell and Bond, 1998). In the system GMM, the variables in levels have as instruments the lagged first-difference of the corresponding variables. To deal with the problem of excessive instruments that arises when sample size increases, we restrict our instruments for the system GMM from the second to the fifth lag. Further, when instruments are valid, Chang et al. (2014) and Lewellen and Lewellen (2016) note that system GMM can employ higher order moments to deal with measurement error problems.

\subsection{Data and descriptives}

We begin our data collection by retrieving a list of all firms from the 15 African countries (Botswana, Cote d'Ivoire, Egypt, Ghana, Kenya, Malawi, Morocco, Namibia, Nigeria, South Africa, Tanzania, Tunisia, Uganda, Zambia, and Zimbabwe) available on Datastream Worldscope Database 
from 1980-2015. There were 4,723 unique firms (5,503 firm-years) identified over the period. Following standard procedures in the literature, we drop 1,971 financial and utility firms (see Faulkender and Wang 2006; Gatchev et al., 2010), ${ }^{5}$ and 2,022 firms with missing data for the construction of key variables. The final sample for our OLS analysis is drastically reduced to 730 unique firms (i.e. 5,503 firm-year observations) from 13 African countries (see Table 1) over the period 20002015. As stated earlier, when utilising the system GMM for robustness testing, we further restrict the sample to those with 5 consecutive years of data, thus, losing an additional 325 firms, ending up with 405 unique firms (3,682 firm-years) from 5 African countries. This filter is imposed to help us generate the required set of instruments to implement the system-GMM regressions. ${ }^{6}$ Finally, all the variables are winsorized at the top and bottom $1 \%$ to reduce the effect of outliers while conserving the sample size.

\section{[PLEASE INSERT TABLE 1 HERE]}

Table 1 presents the descriptive statistics for the study's variables for the full sample (Panel A) and by country and years in Panels B and C, respectively. Firms in our sample generate (on average) $18.3 \%$ of assets in cash flows, and allocate them as follows: $1.4 \%$ of assets to cash holdings, $5.4 \%$ of assets to dividend payments, $8.3 \%$ of assets to capital expenditure (investments), $1.9 \%$ of assets to increase leverage, and $0.3 \%$ of assets to equity issues. Comparing the statistic on equity issues of African firms (0.3\%) to that reported in Gatchev et al. (2010) for US firms (5.1\%) suggests that raising external capital in the form of equity may be a rarity in Africa. The high cash flow allocations to investments and dividend payments by African firms seem consistent with our expectations of corporate behaviour in under-developed financial markets with high external financial constraints. The low allocation to buffer cash holdings is, however, surprising. It is important to note that these are descriptive statistics and do not control for some important determinants of the various uses of cash.

In terms our control variables, the average firm has market-to-book ratio of 1.8 , size of 15.3 , debt ratio of $15.5 \%$, asset tangibility of $35.6 \%$, and cash balance of $12.5 \%$ of the total asset. The statistic on cash balance suggests that African firms exhibit a higher propensity to save as they keep larger cash balances of $12.5 \%$. This compares to $8.0 \%$ held by top US firms (see Harford, 1999), $7 \%$ and $9.1 \%$ cash kept by firms in Czech Republic and Belgium respectively (see Tsoukalas, Tsoukas, and Guariglia, 
2017). In Panel B, internally generated cash flow is particularly high in Tanzania (28.4\%) and Malawi (24.8\%) and low in Uganda (14\%) and Tunisia (15.6\%). Further, time series statistics in Panel C show that cash flow generated by African firms was around $20 \%$ for most of the early years until 2009 when it plummeted to around $17 \%$. This suggests that the recent global financial crisis of 2007-2010 may have adversely impacted corporate cash flow generation on the African continent. We later (in Section 5) examine whether the crisis did change the cash flow allocation patterns of African firms.

Table 2 presents the correlation matrix, with most coefficients having the expected signs. Cash flow (the key variable of interest) is positively correlated with cash holdings, dividends, investments, changes in debt and equity, growth opportunities, firm size, and asset tangibility; but negatively correlated with debt levels. Finally, the correlation among the variables is generally low (with highest correlation coefficient being 0.59 ), suggesting that multicollinearity is unlikely to pose any serious problems to our regression analysis.

\section{[PLEASE INSERT TABLE 2 HERE]}

\section{Results and discussions}

The results estimated using OLS and system-GMM are presented in Table 3. As can be seen, the coefficients for the cash flow variable $\left(C F_{i t}\right)$, representing estimates of the proportion of cash flows allocated towards a particular use, are significant at conventional levels across all models. This implies that operating cash flows have a significant impact on important corporate decisions regarding cash holdings, dividend payments, new investments, and changes in debt and equity capital.

We first discuss the OLS results and compare them with the prior related studies conducted in the US setting. The OLS results in Table 3 suggest that the average African firm allocates its yearly operating cash flows as follows: saves $28.5 \%$, and spends $16.7 \%$ on dividends, $14.6 \%$ on leverage adjustments, $13.9 \%$ on capital expenditure, and $0.8 \%$ on equity repurchases. The results imply that the top (bottom) two priorities of corporate managers of African firms regarding cash usage are cash holding and dividend payments (share repurchases and capital expenditure). By way of comparison with the OLS findings in Lewellen and Lewellen (2016), US firms spend their cash flows in this order: $26 \%$ on capital expenditure, $15 \%$ on cash holdings, $13 \%$ on debt reduction, $13 \%$ on share repurchases, 
and only 6\% on dividends. Similarly, Chang et al. (2014) report that American firms allocate cash flow in the following manner: $33 \%$ cash holding, $29 \%$ debt repayment, $26 \%$ investment, $10 \%$ share repurchases, and $1 \%$ dividend. Thus, US firms seem to prioritise capital expenditure, cash holdings, and debt repayments when allocating cash flow. The striking difference in the cash allocation patterns of African and American firms seems to bother on dividend payment. While African firms appear to rank dividend payment highly, distributions to shareholders through dividends seem to be a less priority in the US.

\section{[PLEASE INSERT TABLE 3 HERE]}

As can be seen from Table 3, the results estimated using system-GMM, which are robust to endogeneity and measurement error concerns, are similar to those of the OLS, following the same pattern of cash allocation. The sys-GMM estimations show that for each unit of additional cash flow generated in a year, managers of African firms save $27.8 \%$ of it, spend $18.8 \%$ on dividends, use $11.7 \%$ to change their leverage, spend only $8.9 \%$ on investments in capital expenditure, and lastly, spend $1.3 \%$ on equity repurchases. Comparatively, sys-GMM results in Chang et al.'s (2014) US study shows the following order of cash allocation: investments (25\%), debt repayment (24\%), savings (20\%), equity repurchases $(11 \%)$, and dividends $(1 \%)$.

The relatively higher (lower) cash allocations by African firms to cash holdings and dividend payments (share repurchases) seem consistent with the existence of financial constraints and the findings in Acharya et al. (2012) who report high cash holdings for financially constrained firms in the US. This high savings from current cash flows suggests a high desire by African firms to hedge against future financing shortfalls, which may be extremely difficult to cover in under-developed capital markets with a higher degree of information asymmetry.

Meanwhile, the high cash flow allocations to dividend payments may suggest that managers of African firms use dividends in an attempt to signal their credit quality to investors in an African environment characterised by high information asymmetry (Gwatidzo and Ojah, 2014). Ravid and Sarig (1991) posit that dividends are a signal of credit quality to investors in the presence of significant information asymmetry. Fama and French (2001) empirically show that larger firms with better operating profitability have higher propensity to pay dividends, which then makes dividends a 
potentially credible tool to signal firm quality in the presence of information asymmetry. Although higher personal tax rate on dividend income may serve as a disincentive for firms paying out dividends to their shareholders (Bagwell and Shoven, 1989), this seems not to be the case for African firms. Perhaps, the weak legal structures coupled with high corruption in most African countries (Gwatidzo and Ojah, 2014) weaken enforcement of African tax laws, and therefore, managers of African firms are emboldened to pay out higher dividends to shareholders.

However, our finding of relatively lower cash flow allocations to investments (capital expenditure) seems surprising. The theory underlying the investment-cash-flow-sensitivity (ICFS) literature suggests that firms that are likely to face external financial constraints should have a higher propensity to fund their investments from their internal cash flow (Fazzari et al., 1988; Kaplan and Zingales, 1997). Applying OLS regressions on a sample of US manufacturing firms from 1970-1984, Kaplan and Zingales (1997) report that firms spend between $20 \%$ and $70 \%$ of their cash flows on investments. Similarly, OLS results in Lewellen and Lewellen (2016) and sys-GMM results in Chang et al. (2014) estimate investment-cash flow sensitivity for US firms to be around $25 \%$. Taken together, US firms seem to spend between $20 \%$ and $70 \%$ of incremental cash flow on investments. Given the difficulty for African firms to access external finance, we expected them to allocate higher proportions of their cash flows to investments. However, our African results surprisingly show a substantially lower sensitivity of cash flows to investments (OLS estimate of $8.7 \%$ and a system-GMM estimate of $8.1 \%$ ).

Our surprising results for African firms, believed to be operating in environments of greater financial constraints, may be explained by the view that investment-cash flow sensitivity may not be a good proxy for the presence of financial constraints (Kaplan and Zingales, 1997; Chen and Chen, 2012). Our finding of lower ICFS for African firms may also imply that African firms are saddled with underinvestment problems. Our results, so far, suggest that managers of African firms may exhibit riskaversion when we consider their high cash flow allocations to cash holdings and dividend payments (the two top priorities) to be "low-risk low-return" projects relative to investments in long-term capital expenditures.

Finally, the low cash flow allocations to debt and equity issues/retirement suggest that African firms may be less active in using internally generated cash flows to adjust their capital structure. This may be 
due to the relatively illiquid bonds and stock markets in Africa, which makes it difficult for firms to easily retire and re-issue securities. Turning attention to the control variables, the proxy for growth opportunities (market-to-book ratio) is significant and positive across most models, except the cash holding model which shows a negative association. This implies that firms with higher growth opportunities hold less cash, pay more dividends, borrow more, and issue more equity. Firm size and asset tangibility were mostly insignificant in several models. The leverage ratio (TDA) is mostly negative and significant, suggesting that firms with existing high debt burden are associated with holding less cash, paying fewer dividends, and making less borrowing. The cash balance is mostly significant, positive in some models and negative in other models.

Lastly, the diagnostic statistics of the models are satisfactory. The OLS models have adjusted Rsquare scores of between 5\% and 51\%, and the F-statistics are significant indicating that the regressors provide a better fit of the models. The $m$-square and $J$-statistic in the GMM models also indicate that there are no concerns with second-order auto-correlation and that the instruments used are valid, respectively.

\section{Robustness testing and further analysis}

In this section, we conduct some further analysis to ascertain the robustness of our results to alternative specifications. In the interest of brevity, we only present OLS results here. As in the previous analysis, the sys-GMM results were qualitatively similar. First, since external financing constraints are more binding on firms during economic recessions and financial crises, we test to see whether our African firms, argued in this paper to be operating in financial constraint environment, maintained their cash flow spending ranking during the recent global financial crisis of 2007-2009. We conduct this test by re-running the baseline model separately for our sub-samples covering the financial crisis period (2007-2009) and the other (non-financial crisis) sample period. As shown in Table 4, the ranking of cash flow spending remained the same across both crisis and non-crisis periods. Specifically, the cash flow spending ranking in both periods followed the previously reported pattern of savings, dividends, debt adjustments, capital expenditure, and equity repurchases. This implies that the recent global financial crisis did not affect the patterns of cash flow spending among African firms. 


\section{[PLEASE INSERT TABLE 4 HERE]}

\section{[PLEASE INSERT TABLE 5 HERE]}

Second, we follow Chang et al. (2014) to decompose our cash flow into a trend (permanent) and cycle (transitory) components to test whether measurement errors in market-to-book ratio, our proxy for firms' growth prospects, could influence our results. Since cycle measures contain little information about the future beyond short-term momentum (Chang et al., 2014), they provide results that are less likely to be contaminated by future growth prospects. The final set of results in Table 4 shows that any potential failure of market-to-book ratio to properly control for firms' growth opportunities did not qualitatively influence our results. The spending rankings of cash holdings, dividends, investments, and so on, remain unchanged.

Third, in the first set of analysis in Table 5, we test whether our findings are unduly driven by South African firms given that they are in the majority. The conclusion of large allocations to savings and dividends holds in both subsamples (South Africa vs. Others), except that dividend is ranked third in the non-South African sample instead of the second position it usually occupies in other reported results. Nonetheless, relative to the prior US studies often ranking dividend at the bottom (fifth), the non-South African firms still seem to prioritise dividend payment.

Fourth, we conduct further analysis (in Panel A of Table 5) with a relatively large sample larger sample which includes financial and utility firms, and the conclusions regarding the order of cash flow allocations remain unchanged. Fifth, in Panel B of Table 5, we test whether external financial constraint may influence cash flow allocation. Following Farre-Mensa and Ljungqvist (2015) and Gopalan et al. (2012), we use asset tangibility, asset liquidity, and Wu \& Whited (WW) index as our proxy for financial constraint. As can be seen, the results are mixed with no explicit ordering of cash allocation across the three proxies. However, cash holding and dividend payments seem to be a top priority for most African firms (constrained and unconstrained), suggesting that the high allocations to dividend may not necessarily be due to the presence of significant financial constraints in African markets. Perhaps, other explanations from the perspectives of risk-aversion of managers and the lack of investment opportunities may better explain this phenomenon. Future studies may consider this issue further. 
Furthermore, in untabulated results, we follow Lewellen and Lewellen (2016) and Chang et al. (2014) to use higher moments in GMM (GMM3, GMM4, and GMM5) to further address the measurement error problem. The results again did not qualitatively change our conclusions. Finally, we conduct analysis based on the baseline specifications often used in the investment-cash-flow sensitivity literature, where investment (use of cash) is regressed on cash flow and market-to-book ratio only. Therefore, in conducting this final analysis, we drop all the regressors in our baseline model in Eq. (1) except cash flow and market-to-book ratio. The results (untabulated) suggest that our findings are robust to alternative specifications.

\section{Conclusions}

We examine cash flow allocations for firms operating in Africa, a market where firms are likely to face significant financial constraints due to relatively less developed capital markets and institutional/infrastructural bottlenecks. Our results show that managers of African firms save a higher proportion of their firms' internally generated cash flows, and when they decide to spend, they tend to prioritise dividend payments over investment in capital expenditure, debt repayments, and equity repurchases. The results also show that the allocations to investments (capital expenditure) are lower than to debt adjustments and only, rank higher than equity repurchases. This high propensity to save is consistent with our prediction of the existence of significant financing constraints in relatively underdeveloped African capital markets, and the need to hedge by hoarding more internal funds. Further, our results are in line with: (1) the use of dividends as a signalling tool for credit quality in environments of higher information asymmetry, and (2) the possible existence of underinvestment problems due to the high risk-aversion exhibited by managers of firms in Africa.

\section{Acknowledgements}

We are grateful to two anonymous reviewers and the Editor-in-Chief, Shahzad Uddin, for their valuable comments/suggestions. Any remaining errors remain ours.

\section{References}


Acharya, V., Davydenko, S.A., and Strebulaev, I.A., (2012), Cash Holdings and Credit Risk, Review of Financial Studies 25 (12), 3572-3609.

Agyei-Boapeah, H., Wang, Y., Tunyi, A., Machokoto, M., \& Zhang, F. (2018, forthcoming). Intangible investments and voluntary delisting: Mass exodus of Chinese firms from U.S. capital markets. International Journal of Accounting and Information Management.

Agyei-Boapeah, H., 2015, Cross-border acquisitions and financial leverage of UK acquirers, Accounting Forum 39 (2), 97-108.

Almeida, H., Campello, M., and Weisbach, M.S. (2004), The Cash Flow Sensitivity of Cash, The Journal of Finance, 59(4), 1777-1804.

Arellano, M., and Bond, S., (1991), Some Tests of Specification for Panel Data: Monte Carlo Evidence and an Application to Employment Equations, The Review of Economic Studies 58(2), 277-297.

Bagwell, L.S., and Shoven, J.B. (1989), Cash Distributions to Shareholders, The Journal of Economic Perspectives 3 (3), 129-140.

Biggs, T. and Shah, M. K. (2006). African SMES, networks, and manufacturing performance. Journal of Banking \& Finance, 30, 3043-3066.

Blundell, R., and Bond, S., (1998), Initial conditions and moment restrictions in dynamic panel data models, Journal of Econometrics 87(1), 115-143.

Boyle, G.W., and Guthrie, G.A. (2003), Investment, Uncertainty, and Liquidity, The Journal of Finance, 58(5), 2143-2166.

Brav, O., (2009), Access to Capital, Capital Structure, and the Funding of the Firm, Journal of Finance 64 (1), 263-308.

Chang, X., Dasgupta, S., Wong, G., and Yao, J. (2014), Cash Flow Sensitivities and the Allocation of Internal Cash Flow, Review of Financial Studies, 27(12), 3628-3657.

Chen, H., and Chen, S., (2012), Investment-cash flow sensitivity cannot be a good measure of financial constraints: Evidence from the time series, Journal of Financial Economics 103 (2), 393-410.

Collier, P. and Gunning, J.W. (1999), Explaining African Economic Performance, Journal of Economic Literature 37(1), 64-111.

Fama, E.F. and French, K.R., (2001), Disappearing dividends: changing firm characteristics or lower propensity to pay?, Journal of Financial Economics 60 (1), 3-43.

Farre-Mensa, and Ljungqvist, A. (2015). Do Measures of Financial Constraints Measure Financial Constraints? The Review of Financial Studies, 29(2), 271-308.

Faulkender, M., and Wang, R. (2006), Corporate Financial Policy and the Value of Cash, The Journal of Finance 61(4), 1957-1990.

Fazzari, S. M., Hubbard, R.G., and Petersen, B.C., (1988), Financing Constraints and Corporate Investment, Brookings Papers on Economic Activity 1, 141-195.

Fosu, S., (2014), Credit information, consolidation and credit market performance: Bank-level evidence from developing countries, International Review of Financial Analysis 32(1), 23-36.

Gatchev, V. A., Pulvino, T., and Tarhan, V. (2010), The Interdependent and Intertemporal Nature of Financial Decisions: An Application to Cash Flow Sensitivities, The Journal of Finance 65(2), 725-763.

Ghosh, A. (2015). Banking-industry specific and regional economic determinants of non-performing loans: Evidence from US states. Journal of Financial Stability 20(4), 93-104.

Gopalan, R., Kadan, O., and Pevzner, M. (2012), Asset Liquidity and Stock Liquidity, Journal of Financial and Qualitative Analysis 47(2), 333-364.

Gwatidzo, T., and Ojah, K. (2014), Firms' debt choice in Africa: Are institutional infrastructure and nontraditional determinants important? International Review of Financial Analysis 31(1), 152-166.

Gyapong, E., Monen, R.M., and Hu, F., (2016), Do Women and Ethnic Minority Directors Influence Firm Value? Evidence from Post-Apartheid South Africa, Journal of Business Finance \& Accounting 43(3-4), 370-413.

Harford, J., (1999), Corporate Cash Reserves and Acquisitions, The Journal of Finance 54(6), 1969-1997.

Kaplan, S.N., and Zingales, L., (1997), Do Investment-Cash Flow Sensitivities Provide Useful Measures of Financing Constraints? The Quarterly Journal of Economics 112(1), 169-215.

Khurana, I.K., Martin, X., and Pereira, R. (2006), Financial Development and the Cash Flow Sensitivity of Cash, Journal of Financial and Qualitative Analysis 41(4), 787-808.

La Porta, R.; F. Lopez-de-Silanes; A. Shleifer; and R. Vishny, (1997), Legal Determinants of External Finance, Journal of Finance, 52(3), 1131-1150.

Lee, I., Lochhead, S., Ritter, J., and Zhao, Q., (1996), The Costs of Raising Capital, Journal of Financial Research 19(1), 59-74.

Lewellen, J., and Lewellen, K. (2016), Investment and Cash Flow: New Evidence, Journal of Financial and Qualitative Analysis 51(4), 1135-1164.

Misati, R. N., and Nyamongo, E.M. (2011), Financial development and private investment in Sub-Saharan Africa, Journal of Economics and Business 63(2), 139-151. 
Modigliani, F., and Miller, M.H., (1963), Corporate Income Taxes and the Cost of Capital: A Correction. The American Economic Review, 53(3), 433-443.

Myers, S.C., and Majluf, N.S., (1984), Corporate financing and investment decisions when firms have information that investors do not have. Journal of Financial Economics 13(2), 187-221.

Ntim, C.G. and Tunyi, A.A. (2016), Location Advantages, Governance Quality, Stock Market Development and Firm Characteristics as Antecedents of African M\&As, Journal of International Management 22(2), 147167.

Opler, T., Pinkowitz, L., Stulz, S., and Williamson, R. (1999), The determinants and implications of corporate cash holdings, Journal of Financial Economics 52(1), 3-46.

Pawlina, G., and Renneboog, L., (2005), Is Investment-Cash Flow Sensitivity Caused by Agency Costs or Asymmetric Information? Evidence from the UK. European Financial Management 11(4), 483-513.

Rajan, R.G., and Zingales L., (1998), Financial Dependence and Growth, American Economic Review, 88(3), 559-586.

Ravid, S.A., and Sarig, O.H., (1991), Financial Signalling by Committing to Cash Outflows, Journal of Financial and Quantitative Analysis 26(2), 165-180.

Ross, Stephen A, 1977, The Determination of Financial Structure: The Incentive-Signalling Approach, Bell Journal of Economics 8(1), 23-40.

Tsoukalas, J.D., Tsoukas, S., and Guariglia, A., (2017), To What Extent Are Savings-Cash Flow Sensitivities Informative to Test for Capital Market Imperfections? Review of Finance, 21(3), 1251-1285.

Yensu, J. (2014). Capital structure, corporate cash holding and dividend policy in African countries (Doctoral dissertation, University of Southampton).

Table 1: Descriptive statistics

\begin{tabular}{|c|c|c|c|c|c|c|c|c|}
\hline \multicolumn{9}{|c|}{ Panel A: Full sample } \\
\hline Variables & $\mathbf{N}$ & Firms & Mean & SD & Min & p25 & p75 & Max \\
\hline $\mathrm{CF}$ & 5,503 & 730 & 0.183 & 0.113 & 0.006 & 0.105 & 0.239 & 0.574 \\
\hline$\Delta \mathrm{CASH}$ & 5,503 & 730 & 0.014 & 0.077 & -0.206 & -0.023 & 0.045 & 0.293 \\
\hline DIV & 5,503 & 730 & 0.054 & 0.063 & 0.000 & 0.013 & 0.069 & 0.328 \\
\hline CAPEX & 5,503 & 730 & 0.083 & 0.069 & 0.000 & 0.034 & 0.112 & 0.355 \\
\hline$\Delta \mathrm{TDA}$ & 5,503 & 730 & 0.019 & 0.098 & -0.304 & -0.020 & 0.053 & 0.383 \\
\hline$\Delta \mathrm{E}$ & 5,503 & 730 & 0.003 & 0.031 & -0.142 & 0.000 & 0.000 & 0.189 \\
\hline MTBV & 5,503 & 730 & 1.800 & 0.950 & 0.632 & 1.138 & 2.196 & 5.497 \\
\hline SIZE & 5,503 & 730 & 15.300 & 1.869 & 10.380 & 14.130 & 16.590 & 18.980 \\
\hline TANG & 5,503 & 730 & 0.356 & 0.209 & 0.018 & 0.184 & 0.517 & 0.818 \\
\hline TDA & 5,503 & 730 & 0.155 & 0.136 & 0.000 & 0.039 & 0.236 & 0.578 \\
\hline $\mathrm{CASH}$ & 5,503 & 730 & 0.125 & 0.107 & 0.002 & 0.046 & 0.172 & 0.514 \\
\hline \multicolumn{9}{|c|}{ Panel B: Statistics by country } \\
\hline Variables & $\mathbf{N}$ & Firms & $\mathbf{C F}$ & $\triangle \mathrm{CASH}$ & DIV & CAPEX & $\triangle$ TDA & $\Delta \mathbf{E}$ \\
\hline Botswana & 21 & 5 & 0.162 & 0.025 & 0.044 & 0.097 & 0.015 & 0.018 \\
\hline Cote D'ivoire & 9 & 3 & 0.187 & 0.006 & 0.089 & 0.091 & 0.034 & 0.008 \\
\hline Egypt & 478 & 76 & 0.184 & 0.016 & 0.074 & 0.063 & 0.013 & 0.011 \\
\hline Ghana & 49 & 10 & 0.209 & 0.021 & 0.025 & 0.136 & 0.012 & 0.015 \\
\hline Kenya & 184 & 30 & 0.187 & 0.013 & 0.070 & 0.088 & 0.013 & 0.003 \\
\hline Malawi & 8 & 2 & 0.248 & -0.010 & 0.029 & 0.163 & 0.060 & -0.001 \\
\hline Morocco & 327 & 48 & 0.192 & 0.002 & 0.072 & 0.067 & 0.014 & -0.001 \\
\hline Nigeria & 200 & 38 & 0.207 & 0.008 & 0.056 & 0.126 & 0.031 & 0.003 \\
\hline South Africa & 3,871 & 458 & 0.181 & 0.015 & 0.050 & 0.083 & 0.021 & 0.001 \\
\hline Tanzania & 22 & 4 & 0.284 & 0.027 & 0.110 & 0.124 & 0.005 & -0.002 \\
\hline
\end{tabular}




\begin{tabular}{lcccccccc} 
Tunisia & 287 & 45 & 0.156 & 0.012 & 0.052 & 0.077 & 0.010 & 0.009 \\
Uganda & 10 & 2 & 0.140 & -0.009 & 0.014 & 0.081 & 0.005 & 0.000 \\
Zambia & 37 & 9 & 0.189 & 0.003 & 0.023 & 0.135 & 0.002 & 0.000 \\
\hline Total & $\mathbf{5 , 5 0 3}$ & $\mathbf{7 3 0}$ & $\mathbf{0 . 1 8 3}$ & $\mathbf{0 . 0 1 4}$ & $\mathbf{0 . 0 5 4}$ & $\mathbf{0 . 0 8 3}$ & $\mathbf{0 . 0 1 9}$ & $\mathbf{0 . 0 0 3}$ \\
\hline
\end{tabular}

The statistics in the table are based on a sample consisting of non-financial firms from 13 African countries over the period from 2000 to 2015. The variables are cash-flow (CF), change in cash ( $\triangle \mathrm{CASH}$ ), dividend (DIV), investments in capital expenditure (CAPEX), change in debt ( $\triangle \mathrm{TDA}$ ), change in equity $(\triangle \mathrm{E})$, market-to-book ratio (MTBV), firm size (SIZE), asset tangibility (TANG), debt ratio (TDA), and cash balance (CASH). All the variables are defined in the Appendix. 
Table 2: Time series statistics and correlation matrix

\begin{tabular}{|c|c|c|c|c|c|c|c|c|c|c|c|c|c|}
\hline Year & All Countries & $\begin{array}{l}\text { South } \\
\text { Africa } \\
\end{array}$ & Others & $\mathbf{C F}$ & $\Delta \mathrm{CASH}$ & DIV & CAPEX & $\Delta$ TDA & $\Delta \mathbf{E}$ & MTBV & SIZE & TANG & TDA \\
\hline 2000 & 153 & 149 & 4 & 0.178 & 0.011 & 0.031 & 0.082 & 0.027 & -0.006 & 1.390 & 15.440 & 0.363 & 0.159 \\
\hline 2001 & 208 & 201 & 7 & 0.221 & 0.043 & 0.044 & 0.083 & 0.016 & 0.003 & 1.484 & 15.410 & 0.328 & 0.150 \\
\hline 2002 & 235 & 226 & 9 & 0.177 & 0.02 & 0.043 & 0.077 & 0.01 & 0.000 & 1.399 & 15.400 & 0.332 & 0.138 \\
\hline 2003 & 292 & 281 & 11 & 0.179 & 0.007 & 0.042 & 0.081 & 0.011 & -0.001 & 1.350 & 15.550 & 0.368 & 0.152 \\
\hline 2004 & 306 & 285 & 21 & 0.186 & 0.026 & 0.042 & 0.085 & 0.002 & 0.002 & 1.560 & 15.630 & 0.349 & 0.141 \\
\hline 2005 & 371 & 286 & 85 & 0.19 & 0.011 & 0.053 & 0.084 & 0.006 & -0.001 & 1.882 & 15.350 & 0.334 & 0.134 \\
\hline 2006 & 407 & 284 & 123 & 0.206 & 0.017 & 0.064 & 0.09 & 0.024 & 0.000 & 2.215 & 15.360 & 0.331 & 0.140 \\
\hline 2007 & 444 & 285 & 159 & 0.21 & 0.024 & 0.062 & 0.095 & 0.028 & 0.001 & 2.237 & 15.170 & 0.336 & 0.155 \\
\hline 2008 & 459 & 293 & 166 & 0.2 & 0.004 & 0.064 & 0.098 & 0.048 & 0.004 & 1.758 & 15.270 & 0.336 & 0.171 \\
\hline 2009 & 454 & 276 & 178 & 0.173 & 0.011 & 0.057 & 0.088 & 0.013 & 0.003 & 1.637 & 15.200 & 0.364 & 0.167 \\
\hline 2010 & 453 & 274 & 179 & 0.165 & 0.014 & 0.052 & 0.075 & -0.005 & 0.004 & 1.779 & 15.230 & 0.379 & 0.150 \\
\hline 2011 & 439 & 262 & 177 & 0.167 & 0.006 & 0.058 & 0.08 & 0.014 & 0.004 & 1.787 & 15.310 & 0.395 & 0.149 \\
\hline 2012 & 384 & 215 & 169 & 0.167 & 0.013 & 0.057 & 0.077 & 0.024 & 0.004 & 1.888 & 15.180 & 0.374 & 0.148 \\
\hline 2013 & 362 & 214 & 148 & 0.167 & 0.009 & 0.055 & 0.074 & 0.031 & 0.003 & 1.913 & 15.100 & 0.365 & 0.169 \\
\hline 2014 & 318 & 193 & 125 & 0.173 & 0.003 & 0.058 & 0.074 & 0.026 & 0.006 & 1.932 & 15.120 & 0.367 & 0.175 \\
\hline 2015 & 218 & 147 & 71 & 0.16 & 0.019 & 0.049 & 0.066 & 0.027 & 0.009 & 1.924 & 15.370 & 0.345 & 0.187 \\
\hline Total & 5503 & 3871 & 1632 & 0.183 & 0.014 & 0.054 & 0.083 & 0.019 & 0.003 & 1.800 & 15.300 & 0.356 & 0.155 \\
\hline \multicolumn{14}{|c|}{ Panel B: Correlation matrix } \\
\hline No. & Variables & & $\mathbf{C F}$ & $\triangle \mathrm{CASH}$ & DIV & CAPEX & $\Delta$ TDA & $\Delta \mathbf{E}$ & MTBV & SIZE & TANG & TDA & CASH \\
\hline 1 & $\mathrm{CF}$ & & 1.000 & & & & & & & & & & \\
\hline 2 & $\Delta \mathrm{CASH}$ & & $0.346 * * *$ & 1.000 & & & & & & & & & \\
\hline 3 & DIV & & $0.511^{* * *}$ & -0.004 & 1.000 & & & & & & & & \\
\hline 4 & CAPEX & & $0.401^{* * *}$ & -0.021 & $0.121^{* * *}$ & 1.000 & & & & & & & \\
\hline 5 & $\Delta \mathrm{TDA}$ & & $0.251^{* * *}$ & $0.067^{* * *}$ & $0.057^{* * *}$ & $0.310^{* * *}$ & 1.000 & & & & & & \\
\hline 6 & $\Delta \mathrm{E}$ & & $0.086^{* * *}$ & $0.136^{* * *}$ & $0.042^{* *}$ & $0.076^{* * *}$ & $0.083^{* * *}$ & 1.000 & & & & & \\
\hline 7 & MTBV & & $0.415^{* * *}$ & 0.010 & $0.585^{* * *}$ & $0.147^{* * *}$ & 0.009 & $0.040^{* *}$ & 1.000 & & & & \\
\hline
\end{tabular}




\begin{tabular}{|c|c|c|c|c|c|c|c|c|c|c|c|c|}
\hline 8 & SIZE & $0.094 * * *$ & -0.013 & $0.070 * * *$ & $0.203^{* * *}$ & $0.107^{* * *}$ & -0.018 & $0.059 * * *$ & 1.000 & & & \\
\hline 9 & TANG & $0.122^{* * *}$ & $-0.121 * * *$ & $0.044 * * *$ & $0.462 * * *$ & 0.021 & $0.058^{* * *}$ & -0.007 & $0.235^{* * *}$ & 1.000 & & \\
\hline 10 & TDA & $-0.030 *$ & $-0.074 * * *$ & $-0.255^{* * *}$ & $0.130^{* * *}$ & $0.369 * * *$ & 0.023 & $-0.203 * * *$ & $0.167^{* * *}$ & $0.252^{* * *}$ & 1.000 & \\
\hline 11 & CASH & $0.207^{* * *}$ & $0.402^{* * *}$ & $0.221^{* * *}$ & $-0.182^{* * *}$ & $-0.120^{* * *}$ & 0.014 & $0.154^{* * *}$ & $\begin{array}{l}- \\
0.209 * * *\end{array}$ & $\begin{array}{l}- \\
0.320 * * *\end{array}$ & $0.369 * * *$ & 1.000 \\
\hline
\end{tabular}


Table 3: Regression analysis of the cash flow uses in Africa

\begin{tabular}{|c|c|c|c|c|c|c|c|c|c|c|}
\hline \multirow{2}{*}{$\begin{array}{l}\text { Model } \\
\text { Variables }\end{array}$} & \multicolumn{5}{|c|}{ OLS } & \multicolumn{5}{|c|}{ GMM } \\
\hline & $\triangle \mathrm{CASH}$ & DIV & CAPEX & $\triangle$ TDA & $\Delta$ EQUITY & $\triangle \mathrm{CASH}$ & DIV & CAPEX & $\triangle$ TDA & $\triangle$ EQUITY \\
\hline $\mathrm{CF}_{\mathrm{it}}$ & $\begin{array}{c}0.285 * * * \\
(0.016)\end{array}$ & $\begin{array}{c}0.167 * * * \\
(0.015)\end{array}$ & $\begin{array}{c}0.139 * * * \\
(0.012)\end{array}$ & $\begin{array}{c}0.146^{* * *} \\
(0.017)\end{array}$ & $\begin{array}{l}-0.008^{*} \\
(0.004)\end{array}$ & $\begin{array}{c}0.278^{* * *} \\
(0.025)\end{array}$ & $\begin{array}{c}0.188^{* * * *} \\
(0.022)\end{array}$ & $\begin{array}{c}0.089 * * * \\
(0.017)\end{array}$ & $\begin{array}{c}0.117 * * * \\
(0.026)\end{array}$ & $\begin{array}{c}-0.013 * * * \\
(0.004)\end{array}$ \\
\hline$Y_{i t-1}$ & & & & & & $\begin{array}{l}-0.021 \\
(0.023)\end{array}$ & $\begin{array}{c}0.360 * * * \\
(0.044)\end{array}$ & $\begin{array}{c}0.529 * * * \\
(0.024)\end{array}$ & $\begin{array}{c}0.053 * * * \\
(0.020)\end{array}$ & $\begin{array}{c}0.056^{* * * *} \\
(0.017)\end{array}$ \\
\hline $\mathrm{MTBV}_{\mathrm{it}-1}$ & $\begin{array}{c}-0.012 * * * \\
(0.001)\end{array}$ & $\begin{array}{c}0.027 * * * \\
(0.002)\end{array}$ & $\begin{array}{c}0.005^{* * *} \\
(0.002)\end{array}$ & $\begin{array}{c}0.001 \\
(0.002)\end{array}$ & $\begin{array}{c}0.001 * * \\
(0.001)\end{array}$ & $\begin{array}{c}-0.016^{* * * *} \\
(0.002)\end{array}$ & $\begin{array}{c}0.016 * * * \\
(0.002)\end{array}$ & $\begin{array}{c}0.001 \\
(0.002)\end{array}$ & $\begin{array}{c}0.006^{* *} \\
(0.003)\end{array}$ & $\begin{array}{c}0.001 * * \\
(0.000)\end{array}$ \\
\hline $\mathrm{SIZE}_{\mathrm{it}-1}$ & $\begin{array}{c}-0.002 * * * \\
(0.001)\end{array}$ & $\begin{array}{c}0.003 * * * \\
(0.001)\end{array}$ & $\begin{array}{c}0.001 \\
(0.001)\end{array}$ & $\begin{array}{c}0.003 * * \\
(0.001)\end{array}$ & $\begin{array}{l}-0.001 * \\
(0.000)\end{array}$ & $\begin{array}{l}-0.001 \\
(0.001)\end{array}$ & $\begin{array}{c}0.000 \\
(0.001)\end{array}$ & $\begin{array}{c}0.000 \\
(0.001)\end{array}$ & $\begin{array}{c}0.003 \\
(0.002)\end{array}$ & $\begin{array}{c}-0.001 * * * \\
(0.000)\end{array}$ \\
\hline TANG $_{\mathrm{it}-1}$ & $\begin{array}{c}-0.027 * * * \\
(0.006)\end{array}$ & $\begin{array}{c}0.004 \\
(0.008)\end{array}$ & $\begin{array}{c}0.120 * * * \\
(0.008)\end{array}$ & $\begin{array}{l}-0.013 \\
(0.010)\end{array}$ & $\begin{array}{c}0.002 \\
(0.002)\end{array}$ & $\begin{array}{c}0.003 \\
(0.013)\end{array}$ & $\begin{array}{l}-0.009 \\
(0.010)\end{array}$ & $\begin{array}{c}0.034 * * * \\
(0.010)\end{array}$ & $\begin{array}{c}0.006 \\
(0.016)\end{array}$ & $\begin{array}{c}0.005 \\
(0.003)\end{array}$ \\
\hline $\mathrm{TDA}_{\mathrm{it}-1}$ & $\begin{array}{c}-0.044 * * * \\
(0.009)\end{array}$ & $\begin{array}{c}-0.086^{* * * *} \\
(0.009)\end{array}$ & $\begin{array}{c}0.001 \\
(0.012)\end{array}$ & $\begin{array}{l}-0.017 \\
(0.016)\end{array}$ & $\begin{array}{c}0.004 \\
(0.003)\end{array}$ & $\begin{array}{c}-0.067 * * * \\
(0.023)\end{array}$ & $\begin{array}{c}-0.036^{* * *} \\
(0.012)\end{array}$ & $\begin{array}{l}-0.008 \\
(0.015)\end{array}$ & $\begin{array}{c}-0.116^{* * *} \\
(0.031)\end{array}$ & $\begin{array}{c}0.001 \\
(0.003)\end{array}$ \\
\hline $\mathrm{CASH}_{\mathrm{it}-1}$ & $\begin{array}{c}-0.148 * * * \\
(0.013)\end{array}$ & $\begin{array}{c}0.082 * * * \\
(0.013)\end{array}$ & $\begin{array}{l}-0.002 \\
(0.012)\end{array}$ & $\begin{array}{c}-0.067 * * * \\
(0.013)\end{array}$ & $\begin{array}{c}0.002 \\
(0.004)\end{array}$ & $\begin{array}{c}-0.200 * * * \\
(0.029)\end{array}$ & $\begin{array}{c}0.074 * * * \\
(0.015)\end{array}$ & $\begin{array}{c}0.031 * * \\
(0.015)\end{array}$ & $\begin{array}{c}-0.173^{* * *} \\
(0.029)\end{array}$ & $\begin{array}{c}0.001 \\
(0.004)\end{array}$ \\
\hline Constant & $\begin{array}{c}0.129 * * * \\
(0.020)\end{array}$ & $\begin{array}{c}-0.082 * * * \\
(0.019) \\
\end{array}$ & $\begin{array}{l}-0.008 \\
(0.039) \\
\end{array}$ & $\begin{array}{l}-0.016 \\
(0.029) \\
\end{array}$ & $\begin{array}{c}0.036 * * * \\
(0.014)\end{array}$ & $\begin{array}{l}0.039 * \\
(0.024) \\
\end{array}$ & $\begin{array}{c}-0.029 * \\
(0.015) \\
\end{array}$ & $\begin{array}{c}0.005 \\
(0.017) \\
\end{array}$ & $\begin{array}{l}-0.041 \\
(0.041) \\
\end{array}$ & $\begin{array}{c}0.025 * * * \\
(0.008)\end{array}$ \\
\hline$N$ & 4,773 & 4,773 & 4,773 & 4,773 & 4,773 & 3,277 & 3,277 & 3,277 & 3,277 & 3,277 \\
\hline$R^{\wedge} 2$ & 0.192 & 0.512 & 0.331 & 0.078 & 0.051 & & & & & \\
\hline$m 2$ & & & & & & 1.378 & -0.0868 & 0.289 & -1.207 & 0.0652 \\
\hline$p$-value & & & & & & 0.168 & 0.931 & 0.773 & 0.227 & 0.948 \\
\hline$J$ & & & & & & 370.8 & 341.8 & 351.0 & 372.1 & 355.2 \\
\hline p-value & & & & & & 0.993 & 1.000 & 0.999 & 0.992 & 0.999 \\
\hline
\end{tabular}


Table 4: Robustness testing: Financial crisis and cash flow components tests

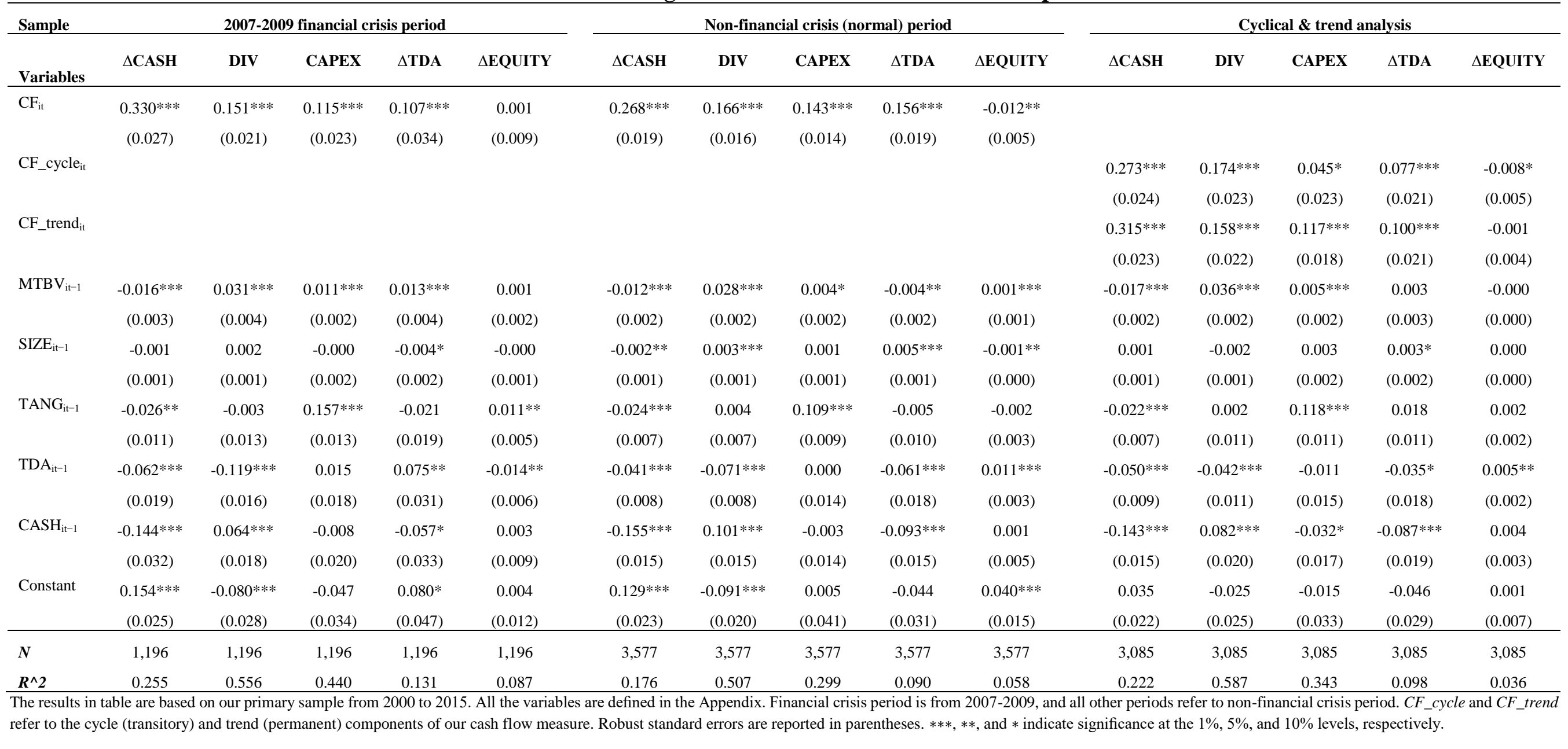


Table 5: Robustness testing: Sampling and financial constraint issues

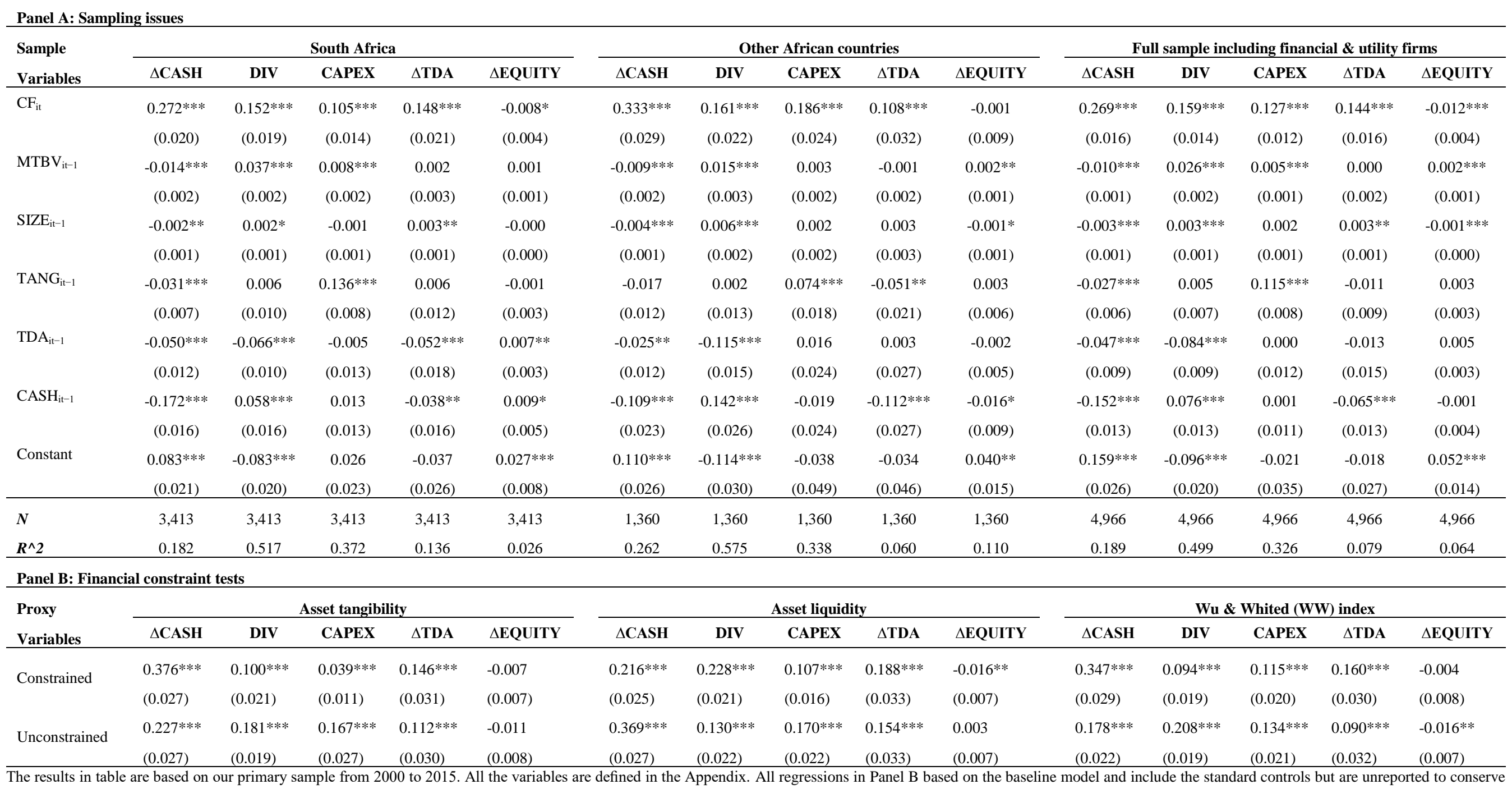

The results in table are based on our primary sample from 2000 to 2015 . All the variables are defined in the Appendix. All regressions in Pare
space. Robust standard errors are reported in parentheses. $* * *, * *$, and $*$ indicate significance at the $1 \%, 5 \%$, and $10 \%$ levels, respectively. 


\section{Appendix: Variable definitions}

\begin{tabular}{|c|c|c|}
\hline Variable & Acronyms & Definition \\
\hline Capital expenditure & CAPEX & Capital expenditure (DWCX) scaled by lagged total assets (WC02999). \\
\hline Dividend pay-out & DIV & Dividends (WC18192) scaled by lagged total assets (WC02999). \\
\hline Cash & CASH & Cash and cash equivalent (WC02005) divided by total assets (WC02999). \\
\hline Cash flow & $\mathrm{CF}$ & $\begin{array}{l}\text { Earnings before interest, tax, depreciation, and amortisation (EBITDA) (WC18198) less changes in working capital } \\
\text { (excluding cash) scaled by lagged total assets (WC02999). }\end{array}$ \\
\hline Working capital & WC & Current Assets (WC02201) less Current Liabilities (WC02005) scaled by total assets (WC02999). \\
\hline$\triangle E Q U I T Y$ & $\Delta \mathrm{E}$ & $\begin{array}{l}\text { Changes in total liabilities \& shareholders' equity (WC03255) less changes in total liabilities (WC03351) scaled by } \\
\text { lagged total assets (WC02999). }\end{array}$ \\
\hline Total debt & TDA & Total debt (WC03255) scaled by total assets (WC02999). \\
\hline$\Delta$ Total debt & $\triangle \mathrm{TDA}$ & Changes in total debt (WC03255) scaled by lagged total assets (WC02999). \\
\hline Market to book value & MTBV & Market capitalisation (WC08001) plus total liabilities (WC03351), scaled by total assets (WC02999). \\
\hline Tangible assets & TANG & Fixed assets (W02501) scaled by total assets (WC02999). \\
\hline Firm size & SIZE & The logarithm of total assets (WC02999) in 2000 prices. \\
\hline
\end{tabular}




\section{Notes:}

${ }^{1}$ Similarly, Ravid and Sarig (1991) and Ross (1977) report that the signalling role of dividends (on the credit quality of the firm) significantly increases with information asymmetry.

${ }^{2}$ Several studies in the US largely focus on ICFS, while overlooking the other uses of cash flows (e.g. Chen and Chen, 2012; Fazzari et al., 1988; Kaplan and Zingales, 1997). These studies regard a stronger (weaker) investment-cash flow-sensitivity to be indicative the presence (absence) of financial constraint. However, the empirical evidence is mixed leading to debates on whether or not ICFS is a good measure of financial constraints (see Chen and Chen, 2012). In the African context, even studies on ICFS and cash flow sensitivity of cash are rare. There are, however, some studies on the determinants of corporate cash holdings in Africa (see e.g. Yensu, 2014). In addition to the cash holdings, Yensu (2014) explores the determinants of dividend policy and capital structure of African firms. Our article differs from the work of Yensu (2014) in that we focus on how current cash flow contributes towards investments, dividend payments, debt repayments, equity repurchases, and savings.

${ }^{3}$ Due to data limitations on African firms, we were unable to include investments such as acquisitions and intangibles in our analysis. This implies that we are unable to provide a complete account of firms spend their cash flow, and thereby, the cash flow identity may not strictly hold in our analysis. It is important to highlight that due to the use of imperfect proxies, the cash flow identity does not always hold even in studies on the advanced economies (see e.g. Table 3 of Lewellen and Lewellen, 2016). These concerns limit our study and the findings should be interpreted with caution.

${ }^{4} \mathrm{We}$ are grateful to an anonymous reviewer for suggesting this approach which helps us to preserve our sample size to cover more African countries (13 instead of 5).

${ }^{5}$ Firms in the financial and utilities industries are often excluded because the heavy regulation of those industries makes their firms completely heterogeneous from other firms. For instance, banks borrow from other banks and/or the Central Bank on completely different terms and are subject to minimum cash holding requirements (i.e. reserve ratio). In fact, when we include these special firms in our analysis, our firm-year observations increase marginally by 193 (from 5,503 to 5,696), and our conclusions remained robust. We, however, decided to follow standard practice by dropping these firms to aid comparison of our findings with prior studies.

${ }^{6}$ The requirement for 5 consecutive years of data helps to generate the required lags and instruments for the lagged dependent variable. In particular, introducing a lag calls for at least 2 consecutive years of data while instrumenting the lagged dependent variable with its differenced variable requires an additional year of data ( 3 years in total).

Meanwhile, sometimes when the moment conditions are not met and instruments fail the validity tests (e.g. Hansen tests) or when using higher moment conditions to minimize measurement error concerns, deeper lags such as the fourth and fifth may be required. 